\title{
INVESTIGATING STUDENT-TEACHER RATIO AS A FACTOR IN READING PERFORMANCE: THE CASE OF THE PHILIPPINES
}

\author{
Aljon Galang \\ Department of Education - Bulacan \\ aljon.galang@deped.gov.ph \\ Inero Ancho \\ Philippine Normal University \\ ancho.iv@pnu.edu.ph \\ Aaron Dela Cruz \\ Department of Education - San Jose Del Monte \\ aaron.delacruz001@deped.gov.ph \\ Ria Dela Cruz \\ Department of Education - San Jose Del Monte \\ Ria.delacruz010@deped.gov.ph
}

\begin{abstract}
This paper attempts to investigate the student-teacher ratio of various Southeast Asian nations and each country's reading performance through the lens of the Programme for International Student Assessment (PISA) scores. This paper employed a purely secondary analysis using data available online. The first phase of the research involved revisiting online documents about the student-teacher ratio in the classroom among selected Southeast Asian nations. In the second phase, reading test scores presented in this study are sourced from PISA. The last phase is the comparison and contrast of the data through a tabular presentation. Findings reveal that the countries with a ratio having the least number of students per teacher ranked higher compared with those with a nation having the greatest number of students per teacher. Singapore, Malaysia, and Brunei Darussalam with a ratio ranging from 8 to 11.6 per teacher scored $408-549$ points in the PISA Reading Test while Thailand, Indonesia, and the Philippines with a ratio ranging from 15 to 36 students per teacher scored 340-393 points. It is undeniable that the student population in the classroom positively impacts the teaching and learning processes, particularly in reading as contextualized in this study. The government should recognize the dire need for schools to provide appropriate funds to sustain the public education system. Careful analysis of the presented data shows the connection between student-teacher ratio and reading performance as manifested by test scores. It is undeniable that the student population in the classroom positively impacts the teaching and learning processes, particularly in reading as contextualized in this study.
\end{abstract}

Keywords: Academic achievement, PISA, Reading performance, standardized test, studentteacher ratio

\section{A. INTRODUCTION}

The quest for a literate society is not a new challenge. Education experts have been working on innovative practices in addressing school children's literacy and reading performance (Saracho, 2017). Apparently, along with emerging challenges in and out of school in contemporary times, reading is one of the primary skills still confronted by gigantic hurdles towards achieving a literate society. 
Classroom interventions are in placed to ensure appropriate and research-based instructional approaches to reading are being observed. However, the problem persists as emerging factors hinder achieving the "every child, a reader" dream. One of these factors that impact students' performance is the student-teacher ratio in our classrooms (OECD, 2019). In a study by Spear-Swerling (2016), it was noted how reading difficulty patterns lead to education-based approaches when it comes to various forms of reading problems.

What is there in the classroom? What observations can be made when reading scores and class size are observed? These are crucial inquiries that have been thoroughly discussed in the literature, but the reality and experience of teachers and students also present a different narrative.

It is said that social realities are experienced in the classroom. The kind of education our school children go through every day is a manifestation of preparing the future generation (Barnes, 2017). Given various social, economic, and cultural considerations, the classroom setting reveals a larger view of one's nation. A cramped and over-populated classroom reflects the inability to provide for the needs of the students: more classrooms, more teachers, and more facilities. Fredriksson, Ockert, and Oosterbeek (2016) found out that students who belong to low-income families taught in big class sizes struggle in following their teachers.

On the other hand, a carefully planned and designed learning area extends how the government can invest in public education. According to Kelleher and Weir (2018), Ireland has been reducing continuously working to decrease the ratio of students. The same effort is also seen visible in other countries. Schanzenbach (2020) argued that "Class-size reduction is a politically popular but relatively expensive education reform." Current literature suggests the need to examine whether academic interactions are affected by class size. (Beattie and Thiele, 2016).

Standardized tests provide sensible inputs to policymakers and experts in the field of education towards effective and efficient planning and allocation of available resources, among others. These examinations serve as a call in situating the education system's status to weigh whether student performance is at par or lags relative to other countries (International Literacy Association, 2017).

This paper attempts to investigate the student-teacher ratio of the Philippines, vis-à-vis various Southeast Asian nations, and each country's reading performance through the lens of the Programme for International Student Assessment (PISA) scores. As part of a larger study, this initial inquiry hopes to shed light on the relation of student-teacher ratio and academic achievement in the context of PISA test result. Basically, this study presents the status of the 
Philippines concerning practices of neighbouring countries when it comes to student-teacher ratio in the classroom. It is hoped that the findings of the study could serve as inputs in crafting sound policies when it comes to designing the classroom setup, particularly the student-teacher ratio, based on the observed effect on students' performance through standardized tests such as PISA.

This study particularly looks at the context of reading scores in a standardized test as it provides opportunities for students to access the depth and breadth of their academic experience. With the release of the PISA results, it was revealed that Filipino students fared lower compared to their ASEAN counterparts. With the country's literacy rate pegging at $97.95 \%$, one would ask: what went wrong?

The findings of the study also offer a reflection on the practices of other nations concerning the test performance of the students. As White (2016) suggested, there is a need for collaboration, particularly in the teacher education research community, to develop lasting and effective policies.

\section{B. REVIEW OF LITERATURE}

Linguistic proficiency, being the tool to learn the other disciplines such as science and mathematics (Smith, 2017; Teacher Education through School-Based Support in India, n.d.), has been on top of the lists of experts in language education. Reading, being one of the two (2) essential linguistic receptive macro-skills (British Council, n.d.), is the target of pedagogy aiming its full enhancement among the learners; thus, it has always been the major target skill of Programme for International Student Assessment (PISA) in 2000, 2009, and 2018 (OECD, 2018). However, the skill's enhancement is indeed a challenging task, especially to language educators. In other words, teaching reading must be further improved.

Moreover, to achieve improvement, there must be a springboard that can assist educational experts to create innovation in instruction. PISA provides data that can be used for the critical analysis and reflection of a country's educational policy. Moreover, adapting Chomsky's concept of language learning, the data scores in reading may not gauge the total linguistic competence of the test takers, but it reflects its shadow, linguistic performance (Radford, 1988). Enhancement of academic performances of any kind, however, requires positive classroom management.

One of the most indispensable elements of learning reading is classroom management. Positive classroom management can be achieved when students are in a learning milieu free of distraction and aided with teacher guidance. Along with strategies, student academic 
engagement can be improved (Kratochwill, DeRoos, \& Blair, 2020). Nonetheless, in some Southeast Asian classrooms, learning distraction and teacher classroom guidance are perplexities due to the ratio of student-teacher in a class. This is brought about by the shortage of teachers in remote areas (Sadiman, 2004).

Though there is no clear link between student-teacher ratio and learning reading, the PISA 2018 reading test results show that there is a problem in the teaching and learning reading process in the countries. In the Philippines, upon the release of the disappointing results, its Department of Education has launched the program 'EduKalidad' aiming to address this national education issue (Department of Education, 2019), but there is no clear objective focusing on student-teacher ratio.

Reduced class size, though a costly approach yields promising gains when it comes to academic achievement (Mathis, 2017). Several education systems around the world have been designing the realm of teaching and learning to accommodate optimal class size. Ndidi and Effiong (2020) also supported this claim as students' academic performance could also be improved by considering class size along with sufficient government fund allocation and availability of teachers' instructional materials. The size of the class has also been seen as a "potent predictor of academic achievement" (Abosede, 2018). Filges, et al. (2018) opined that due to a small number of students in a class, chances are the teacher will be able to devote more time and consideration. The issue on class size and students' academic achievement may have been an old debate but recent studies have consistently supported this advocacy. Even in the context of higher education, a positive link can be seen between class size and academic achievement of students (Owuor, 2018).

A study by Nadrup (2014) in the Danish public school system supported that small class size positively impacts student achievement in reading and math and physics. Using Tennessee's Project STAR as a reference, Murphy (2010) stated that children in smaller classes were able to "achieve higher levels in reading," with similar observations of performance in other areas such as social studies, science, math, and others. Similarly, Monks \& Schmidt, (2010) made a reference to a study conducted by Krueger (1999) who stated that better performance was observed among students in smaller classes in terms of their math and reading scores. Finn (2002) highlighted the experience of students who were part of small classes regarding their reading scores, citing that a year of attendance yielded a 1.2-month advantage compared to those from large classes. Also, Zinth (2009) research supported the findings that students' performance in reading and math has improved as they attend classes with reduced size. 
Though there is no empirical evidence at hand, the student-teacher ratio is undeniably treated as one of the tacit factors affecting not only the reading skill edification of the learners but also their other learning skills and yet, the Organization for Economic and Co-operation Development (OECD) claims that there is a weak empirical foundation that it is a factor to consider in learning. Though the organization states that younger learners and those from disadvantaged roots may benefit from smaller classes, the organization still adds no agreement among countries on the student-teacher ratio (OECD, 2019). Due to the dilemma, it is worthy of studying the PISA 2018 results and the student-teacher ratio within the parameters of the Southeast Asian nations to investigate the existence of a link between learning reading and student-teacher ratio.

\section{RESEARCH METHOD}

This paper employed purely secondary analysis, using data available online (Neuman, 2007). The first phase of the research involved looking at online documents about the student-teacher ratio in the classroom among selected Southeast Asian nations. While there is no single data that provided all the needed information, the researchers exhausted multiple sources to develop the most recent figures that were then tabulated. This study's reading test scores are sourced from the Programme for International Student Assessment (PISA). The study primarily looks at the Philippine setting with reference to neighboring countries in the Asean region. Data, however, is limited only to those available online; only the following countries were only presented: Brunei Darussalam, Indonesia, Malaysia, The Philippines, Singapore, and Thailand.

After gathering the needed data for the student-teacher ratio and reading test scores, the researchers started the analysis by looking at the essence of each reported figure. Since this study is concerned with available documents online, it bears no ethical concerns. References are properly cited and ethical treatment of gathered data was observed.

\section{FINDINGS AND DISCUSSION}

Due to the results of the 2018 PISA, many countries contemplate their educational systems and their quality particularly in reading, mathematics, and science. The Association of Southeast Asian Nations (ASEAN) is one of the international community allies that are alarmed because of the findings. Furthermore, spearheaded by its Department of Education, the Philippines, being at the bottom, creates a bold move to revisit its curriculum - its design 
and implementation. The country's legislative bodies, both the Upper and Lower Houses, also take part in addressing the existing educational catastrophe.

The economic status and demographics (ECD) of a country affect its progress, indeed. Once the economy is weak and the population is in a multitude, there is a possibility of local congestion and material scarcity. This ECD effect may extend from the breadth of national transactions to the depth of micro-communities such as the school. Overpopulation is a problem of many third world countries, especially in Southeast Asia extending to their teaching-learning institutions. The lack of buildings and qualified teachers is the perennial issue of today. There are not enough teachers who can cater to the needs of the students. Consequently, these countries need to make use of their qualified human resources wisely.

\section{Population and Education: When Less Is More}

In the Philippines, since the number of teachers is not proportionally judicious to the number of students, its Department of Education struggles in educating the school children. It is rooted in its economic troubles. Due to this reason, the government finds it a challenge to pay enough qualified teachers and provide instructional resources that can cater to the growing population of students in the country. However, ideally, there must be a considerable number of students in a class so that the teacher can manage their needs properly, not only at the elementary level but also at the secondary level. Nonetheless, it is not what the Philippine reality shows.

\section{Testing Reading as a Literacy Indicator}

Reading is undeniably the most essential and universal indicator of literacy. It confirms the ability of an individual to receive data and information leading to synthesis and other forms of innovation from individual achievements to national heights. The failure to attain reading virtuosity or at least sufficient skill may lead to an academically low-level stagnant student. To avoid it, a constant evaluation must be done through a test such as PISA. However, it may be an accurate tool to gauge the students' skill level, but it can only measure what is exhibited now of its implementation. Though it does not reveal a student's competence in a skill, at least, it provides evaluative and/or diagnostic insights to re-design a curriculum and improve its execution through instruction.

Thus, it is high time to analyze the Philippines' educative arena, particularly in reading, along with the other ASEAN countries as a point of comparison and contrast. These are done to provide insights to improve the educational system of the Philippines and other ASEAN countries. 
Primarily, the data are derived from OECD PISA 2018 Results and UNESCO Institute for Statistics. Others are taken from other sources, such as the Philippine News Agency (PNA) and Education Statistics Digest (ESD) of the Singaporean Ministry of Education. This is due to data unavailability and outdatedness in the primary sources. The data provided above are limited to ASEAN countries only. However, the analysis focuses on the PISA 2018 participants only such as Brunei Darussalam, Indonesia, Malaysia, the Philippines, Singapore, and Thailand. Non-participants are also indicated in the table such as Cambodia, Lao PDR, and Myanmar (Andreas, 2018). Viet Nam joined in PISA 2018 using paper-based testing tools. When the report was published, the international comparability of Viet Nam's performance in reading, mathematics, and science could not be fully ascertained. Thus, the OECD does not include Viet Nam's performance in the report (Organization for Economic Co-operation and Development [OECD], 2018).

\section{Going through the Student-Teacher Ratios across ASEAN Secondary Schools}

While the pupil-teacher ratios in the primary schools must also be considered, the focal point of comparison and contrast in this paper is only made on the secondary school students since the PISA participants are 15 years old who belong to the school level. Following is the table showing the differences between the country participants in terms of student-teacher ratios (OECD, 2018).

\begin{tabular}{c|c}
\hline ASEAN Country & Student-Teacher Ratio (2018) \\
\hline Brunei Darussalam & $8: 1$ \\
\hline Indonesia & $15: 1$ \\
\hline Malaysia & $11: 1$ \\
\hline The Philippines & $36: 1$ \\
\hline Singapore & $11.6: 1$ \\
\hline Thailand & $24: 1$ \\
\hline
\end{tabular}

Table 1. ASEAN PISA 2018 Participants' Student-Teacher Ratios in Secondary Schools (MES, 2019; WBG, 2019)

As shown above, the countries with the greatest number of students per teacher (CMNS) are the Philippines having 36 students per teacher, Thailand with 24, and Indonesia with 15. 
Among the six, Brunei Darussalam having 8, Malaysia with 11, and Singapore with 11.6 are countries with the least number of students per teacher (CLNS) (MES, 2019; WBG, 2019). On the one hand, the Philippine-Thailand ratio difference (RD) is 12 and on the other hand, Philippine-Indonesia is 21. Furthermore, while Brunei Darussalam-Malaysia RD is 3 , the Brunei Darussalam-Singapore RD is 3.6. Thus, this shows that there is a wide range of differences in terms of student-teacher ratios when CMNS and CLNS are compared. Nonetheless, aside from the student-teacher ratio, another variable to consider is the PISA 2018 Reading Level Results.

\section{ASEAN Reading Skill as Measured by PISA 2018}

The table below shows the reading level of the participants' test results and their test scores. The data are compared to reveal their score differences $(\mathrm{ScD})$ as a springboard for analyses.

\begin{tabular}{c|c|c}
\hline ASEAN Country & $\begin{array}{c}\text { PISA Reading Level } \\
\text { Result (2018) }\end{array}$ & Score \\
\hline Brunei Darussalam & Level 2 & 408 \\
\hline Indonesia & Level 1a & 371 \\
\hline Malaysia & Level 2 & 415 \\
\hline Thailand & Level 1a & 393 \\
\hline The Philippines & Level 1a & 340 \\
\hline Singapore & Level 3 & 549 \\
\hline
\end{tabular}

Table 2. ASEAN PISA 2018 Participants' Reading Level and Test Scores (Andreas, 2018)

As shown in Table 2, on the one hand, the countries who are above Level 1 (AL1) are Singapore being Level 3, having 549 points, Malaysia and Brunei Darussalam being Level 2, the former with 415 points and the latter with 408. On the other hand, the Philippines, Indonesia, and Thailand are within Level 1a (WL1). The first accumulated 340 points, the second gathered 371, and the last had 393 (Andreas, 2018). Moreover, among the AL1 countries, Singapore-Malaysia's ScD is 134 points and the Singapore-Brunei Darussalam's is 141. Besides, among WL1 countries, Philippine-Indonesia's ScD is -31, and PhilippineThailand's is -53 . 
Thus, this shows that there is a wide range of differences in terms of PISA 2018 score differences when AL1 and WL1 countries are compared. However, the student-teacher ratio and the PISA 2018 reading test scores must also be compared.

\section{Student-Teacher Ratio as a Factor in Reading Performance}

Now that the student-teacher ratio and test scores are analyzed individually, the two must be compared to identify if there is a relationship between the two variables at hand.

\begin{tabular}{c|c|c|c}
\hline ASEAN Country & Level & $\begin{array}{c}\text { PISA Reading } \\
\text { Test Score }\end{array}$ & $\begin{array}{c}\text { Student-Teacher } \\
\text { Ratio (2018) }\end{array}$ \\
\hline \hline Singapore & 3 & 549 & $11.6: 1$ \\
\hline Malaysia & 2 & 415 & $11: 1$ \\
\hline Brunei Darussalam & 2 & 408 & $8: 1$ \\
\hline Thailand & 1a & 393 & $24: 1$ \\
\hline Indonesia & 1a & 371 & $15: 1$ \\
\hline The Philippines & 1a & 340 & $36: 1$ \\
\hline
\end{tabular}

Table 3. PISA 2018 Reading Test Scores and Student-Teacher Ratio (Andreas, 2018; MES, 2019; WBG, 2019)

Obviously, the countries with a ratio having the least number of students per teacher ranked higher than those with a ratio having the most number of students per teacher. Singapore, Malaysia, and Brunei Darussalam, with a ratio ranging from 8 to 11.6, scored 408549 points in the PISA Reading Test, while Thailand, Indonesia, and the Philippines, with a ratio ranging from 15 to 36, scored 340-393 points (Andreas, 2018; MES, 2019; WBG, 2019). Thus, it could be noted that if there is a low number of students per teacher, there is a possibility that the performance as reflected in scores would be higher.

Out of this, it is suggested that there must be a considerable number of students in a class to focus more on their needs, particularly in reading, which requires ample patience and guidance. Teachers cannot work properly if there are many students with varied needs to focus on. Thus, the Philippine government, especially the Department of Education, and other ASEAN countries are encouraged to re-visit their national education policies considering the student-teacher ratio. PISA 2018 non-participants and Viet Nam must also consider this matter seriously. 
However, it could be observed that in the case of Singapore and Malaysia, both countries reported to have almost similar student-teacher ratios but exhibit significantly different reading scores. Given this data, it could be gleaned that while the student-teacher ratio could provide significant inputs on test performance, this alone cannot be utilized as a sole determinant. In the case of the Philippines having the greatest number of students in the classroom and apparently having the lowest score in the region, revisiting the policies on student-teacher ratio could shed light on the issue.

While student-teacher ratio alone cannot be treated as the sole factor that impacts reading scores, the data presented in this paper clearly provides the discourse on how the Philippines fare in terms of student-teacher ratio and reading scores as compared to its neighboring countries in the ASEAN region.

The countries' student-ratio in the tables above ranges from 18-29 per teacher (World Bank Group, 2019). Low scores may occur when this is not addressed. There is a crucial need to consider the number of students in a class to improve their students' reading skills properly so that when they participate in the next PISA, they will perform better and benefit the Southeast Asian Nations as a whole.

\section{E. CONCLUSION}

Careful analysis of the presented data shows a seemingly notable connection between student-teacher ratio and reading performance as manifested by test scores. As observed, it could be noted that student population in the classroom could positively impact the teaching and learning processes, particularly in reading as contextualized in this study. Considering the findings of this study, the following conclusions and recommendations are made:

1. Small student-teacher ratio could possibly yield favorable outcomes. Higher PISA scores are achieved by those countries with a relatively small student-teacher ratio. Scores, however, tend to decrease as the ratio increases. Focus on class is essential to achieve the optimal reading skill and it foes with class size.

2. Proactive investment in education is one key to academic achievement. The government should recognize the dire need for schools to be provided with appropriate funds to sustain the public education system. This could be done by constructing more classrooms to decongest classes, hiring more teachers who can fulfill the duties, and providing appropriate instructional materials.

3. Fact check, reality check, check, and balance for accountability. While standardized tests offer inputs for policy measures and decisions, other strategies should be in place to determine the status 
of the education system. Assessments and monitoring should be religiously and authentically done at the local and national level, vis-à-vis target results. Troubleshooting mechanisms should be adopted to address emerging needs. A system should be in place to determine accountable agents as outcomes and results are revealed.

4. Reflective practices as a springboard of academic success. While there are economic factors to consider in terms of budgeting and fiscal management in the education system, teachers are at the forefront of challenging innovation inside the classroom. Equipped with a dynamic mindset and proactive skills, teachers may employ strategies suitable for a relatively large classroom population. The technology could be exhausted and appropriate approaches could be tapped and maximize bypassing the burden of undesirable student-teacher ratio.

The study also poses numerous limitations and suggestions for future inquiries are also identified by the researchers. In the future, it would be worthy to include many country participants, beyond the ASEAN region. This way, the depth and breadth of the study could be clearly established. Given these samples, subjecting student-teacher ratio and reading scores to statistical tests and analysis could shed light in terms of quantitative inquiries. Current study is focused on a limited data, thus future studies could employ appropriate statistical treatment to establish clear relationships among the variables.

\section{REFERENCES}

Abosede, S. C. (2018). School Location, Class Size and Teaching Experience as Determinants of Academic Achievement of Students' in Lagos State. KIU Journal of Humanities, 2(2 (B)), 243-252.

Andreas, S. (2018). Comparing countries' and economies' performance in reading. PISA 2018: Insights and interpretation, 7. Retrieved from https://www.oecd.org/pisa/PISA \%202018\% 20Insights $\% 20$ and $\% 20$ Interpretations $\% 20$ FINAL $\% 20$ PDF.pdf

Barnes, M.R. (2017). Education and social reality: Thought and reflection. Retrieved from https://www.academia.edu/33062197/Education_and_ Social_Reality_Thought_and_Reflection?auto=download

Beattie, I. R., \& Thiele, M. (2016). Connecting in class? College class size and inequality in academic social capital. The Journal of Higher Education, 87(3), 332-362.

British Council. (n.d.). Receptive skills. Teaching English. Retrieved from https://www.teachingenglish.org.uk/article/receptive-skills

Department of Education. (2019). Sulong edukalidad: DepEd's battle cry moving forward. Retrieved from https://www.deped.gov.ph/2019/12/03/sulong-edukalidad-depedsbattlecry-moving-forward/ 
International Literacy Association. (2017). Roles and uses of standardized tests. Retrieved from https://literacyworldwide.org/docs/default-source/where-we-stand/ila-rolesstandardized-reading-tests-in-schools.pdf?sfvrsn=c6ada58e_4

Filges, T., Sonne-Schmidt, C. S., \& Nielsen, B. C. V. (2018). Small class sizes for improving student achievement in primary and secondary schools: a systematic review. Campbell Systematic Reviews, 14(1), 1-107.

Finn, J. D. (2002). Class-size reduction in grades K-3. School reform proposals: The research evidence, $27-48$.

Fredriksson, P., Öckert, B., \& Oosterbeek, H. (2016). Parental responses to public investments in children: Evidence from a maximum class size rule. Journal of Human Resources, 51(4), 832-868.

Kelleher, C., and Weir, S. (2016). Class size and the student-teacher ratio at primary level in Ireland and other OECD countries. The Irish Journal of Education, 41, 39-60.

Kratochwill, T., DeRoos, R., \& Blair, S. (2020). Classroom management module. American psychological association. Retrieved from https://www.apa.org/education/k12/modules-classroom-management

Mathis, W. J. (2017). The effectiveness of class size reduction. Psychosociological Issues in Human Resource Management, 5(1), 176-183.

Ministry of Education Singapore. (2019). Ratio of students to teaching staff. Education Digest 2019, xvi. Retrieved from https://www.moe.gov.sg/docs/defaultsource/document/publications/education-statistics-digest/esd_2019.pdf

Monks, J. \& Schmidt, R. (2010). The impact of class size and number of students on outcomes in higher education [Electronic version]. Retrieved [insert date], from Cornell University, School of Industrial and Labor Relations site: http://digitalcommons.ill.cornell.edu/workingpapers/114/

Montemayor, M.T. (2018, March 19). Class size affects students' learning: DepEd. Philippine National Agency. Retrieved from https://www.pna.gov.ph/articles/1029281.

Murphy, J. (2010). An Investigation of the Effects of Class Size on Student Achievement in Title I Elementary Schools: A Mixed Methods Study. Dissertation. Virginia Commonwealth University. Retrieved from https://scholarscompass.vcu.edu/cgi/viewcontent.cgi?article=3170\&context=etd.

Nadrup, A. B. (2014). Do Class Size Effects Differ Among Grades? Department of Economics and Business, Aarhus University. Retrieved from http://www.iwaee.org/PaperValidi

2014/20140214103857_140127_Do_Class_Size_Effects_Differ_Across_Grades.pdf

Ndidi, M. A., \& Effiong, I. E. (2020). Influence of Classroom Environment on Senior Secondary School Students' Academic Achievement in Mathematics in Calabar Nigeria. Educational Research and Reviews, 15(8), 495-503. 
Neuman, W.L. (2007). Basics of social research: Qualitative and quantitative approaches $\left(2^{\text {nd }}\right.$ ed.). Boston, MA: Pearson Education Inc.

Organization for Economic Co-operation and Development. (2019). Class size \& studentteacher ratio. Retrieved from https://gpseducation.oecd.org/revieweducationpolicies $/ \# !$ node $=41720 \&$ filter $=$ all

Organization for Economic and Co-operation Development. (2019). PIS A 2018 assessment and analytical framework. Retrieved from https://www.oecd-ilibrary.org/docserver/ b25efab8-en.pdf?expires $=1591432577 \& i d \quad=i d \& a c c n a m e=$ guest $\quad$ achecksum $=$ 37FF4461EBDA9C73FFD2CF48D441B84A

Organization for Economic Co-operation and Development. (2018). Viet Nam in PISA 2018. Retrieved fromhttps://www.oecd.org/pisa/publications/PISA2018 CN VNM.pdf

Owuor, N. A. (2018). Class Size and Student Achievement. UKH Journal of Social Sciences, 2(1), $19-24$.

Radford, A. (1998). Transformational grammar. Great Britain: Cambridge University Press.

Saracho, O. (2017). Literacy and language: new developments in research, theory, and practice. Early Child Development and Care. Retrieved from https://www.tandfonline.com/doi/full/10.1080/03004430.2017.1282235? src=recsys

Sadiman, A. (2004). Problem of equity in education. Southeast Asian ministers of education organization. Retrieved from https://www.seameo.org/VL/library/ dlwelcome/publications/paper/india04.htm

Schanzenbach, D. W. (2020). The economics of class size. In The Economics of Education (pp. 321-331). Academic Press.

Smith, O. (2017). The influence of language on the teaching and learning of mathematics. Retrieved from https:// scholarworks.waldenu.edu/cgi/viewcontent.cgi?article $=5962 \&$ context $=$ disserta tions

Spear-Swerling, L. (2016). Common types of reading problems and how to help children who have them. The reading teacher, 69(5), 513-522.

Teacher Education through School-Based Support in India. (n.d.). Language in the science classrooms: cell. Retrieved from https://www.open.edu/openlearncreate/ pluginfile.php/ $145519 / \mathrm{mod}$ resource/content $/ 2 /$ SS08 AIE Final.pdf

White, S. (2016). Teacher education research and education policy-makers: An Australian perspective. Journal of Education for Teaching, 42(2), 252-264

World Bank Group. (2019). Pupil-teacher ratio, secondary. Retrieved from https://data.worldbank.org/indicator/SE.SEC.ENRL.TC.ZS

Zinth, K. (2009). State Policies Focusing on Class-size Reduction. Primer. Education Commission of the States. Retrieved from http://www.ecs.org/clearinghouse/81/95/8195.pdf. 